Vol. XXIII No $2 \quad 2017$

\title{
MASS-MEDIA COMMUNICATION IN ROMANIA
}

\author{
Ioana-Narcisa CREȚU \\ "Lucian Blaga" University of Sibiu, Romania \\ ioana.cretu@ulbsibiu.ro
}

\begin{abstract}
Over 1200 new publications have appeared in Romania since the fall of communism. Some of them don't exist anymore, but there always appear new ones. The Romanian newspaper market comprises about 1500 publications most of which appear on a weekly basis and 200 daily newspapers. Television is the most familiar source of information. The radio landscape has changed considerablysimilar to the television - since 1990. Besides the public broadcaster offering several programs, there are over 150 private local radio stations and various other channels. Despite the diversity of the Romanian press, we cannot yet speak of a completely free press (see the report of the Freedom House organization). The limitations of media freedom and freedom of speech are related to media ownership, but also with gaps in the national legislation. This study aims to contribute to the advancement in the conceptualization of qualitative journalism by proposing to analyze different situations of failure in investigative journalism and identifying factors that conduct to limitation of media freedom.
\end{abstract}

\section{Keywords: freedom of the press, media landscape, Romania, qualitative journalism}

\section{Introduction}

The limitations of media freedom and freedom of speech despite of pluralism of the press in former communist countries in Southeast of Europe, especially in Romania and Moldavia, are related to media ownership as in [1], mentioned by Active Watch in 2008 as in [2] and 2016 as in [3], but also with gaps in the national legislation as in [4]. For quality in investigative journalism in this countries are still fighting the members of the Rise Project by encouraging the civil society to send documents to the platform RiseLeaks, a similar safety system to the popular WikiLeaks as in [5]

This study aims to contribute to the advancement in the conceptualization of quality journalism by proposing to analyze different situations of failure in investigative journalism and identifying factors that conduct to limitation of media freedom. The choice of the case studies is related to the impact of the media ownership (case 1 and 2) and quality journalism (case 3 ) in Romania.

\section{National Media Landscape \\ 2.1. Printed press}

Over 1200 new publications have appeared in Romania since the fall of communism. Some of them don't exist anymore, but there always appear new ones. The Romanian newspaper market comprises about 1500 publications most of which appear on a weekly basis and 200 daily newspapers, 14 of them published in Bucharest and between 1 and 5 in the capitals of Romanian counties. Despite the diversity of the Romanian press we cannot yet speak of a completely free press: report of the Freedom House organization as in [6].

The best sold daily papers in Romania are still the tabloids: Click - with an average of 587,000 readers per issue and Libertatea with 468,000 (23rd of January 2012December 2013), followed by the sport paper Gazeta sporturilor (338.000 readers), 
Pro Sport (318.000 readers) and the daily paper Jurnalul Naţional (187.000 readers), Adevărul (157.000 readers), Evenimentul zilei (150.000 readers), the financial paper Ziarul financiar (78.000 readers) and România liberă with 67.000. All newspapers have lost readership except ProSport, which won 10.000 new readers.

The best-sold weekly journals are destined for women: Libertatea pentru femei with 351.000 readers, Click pentru femei with 368.000 readers and Femeia de azi with 208.000 readers.

The best sold monthly publications are: Practic in bucătărie with 997.000 readers, Libertatea pentru femei - Reţete with 548.000 readers, Click poftă bună- 482.000 readers, Click Sănătate - 446.000 readers.

Regarding the circulation development of printed media it should be mentioned that their total number remained relatively constant until 2008, but now it follows the overall trend of decreasing.

In Romania the printed sector has been dealing with big difficulties since the beginning of the economic crisis as in [7]. In February 2012, three daily papers had to be discontinued, Cotidianul, Ziua and Gardianul, after their circulation had declined dramatically. Evenimentul zilei, occupies with almost 45.000 issues the third place among the best-read informative daily papers in Romania, after Adevărul and Jurnalul National as in [8]. The circulation had already decreased in 2009 by 3, $7 \%$, in the case of Capital the decrease was by 9 , 1. Romania's most successful daily journal Adevărul is the only one from this segment to have raised its circulation in 2009 - by $14,1 \%$ to over 120.000 as in [9]

\subsection{Television in Romania}

Television is the most familiar source of information, however the range of the private stations only covers 50 to $72 \%$ of the population, while the public service one reaches almost $100 \%$. In the cities the public television (TVR1 and TVR2) only reaches $35 \%$ of the market, placing itself below the private stations.
The most important private station is ProTV, with a range of $72 \%$ of the population and a market share of $15,8 \%$. In March 2014 the following ranking list was compiled: ProTV, Antena 1, Antena 3, Kanal D, Prima TV, România TV, National TV, B1TV, Acasă, TVR 1. For 2012, the following ranking was prepared according to income: Pro TV, Antena 1, Acasă, Kanal D, Antena 3, Prima TV, TVR1, Realitatea TV, National TV, Diva Universal. The situation of the public service broadcast stations is however better, Radio România did not suffer any losses, on the contrary, it gained audience, even if the gain was modest (2007).

\subsection{Radio landscape}

The radio landscape has changed considerably - similar to the television since 1990. Besides the public broadcaster offering several programs, there are over 150 private local radio stations and various other channels (sectarian or foreign channels). The local radio stations air mostly music and short newscasts.

The most important private stations are: Kiss $F M$, with 2,774 million listeners and a market share of $13,2 \%$, Radio România Actualităţi with 2,013 million listeners and a market share of $13,4 \%$, ProFM, Radio ZU, Europa FM, Antena Satelor, Radio 21, MagicFM. In Bucharest dominates Radio $\mathrm{Zu}$.

Out of these: Europa FM and Radio 21 had the biggest profit quotas in 2007 amongst radio stations.

\subsection{The Internet}

The last studies showed that 5,9 million Romanians use the Internet daily, which represents $61,6 \%$ of the population and the trend is rising.

\section{Freedom of the Press}

The report of the Freedom House organization places Romania 84th in the top, it belongs to the countries with a partially free press. The investigation concerns 197 countries from all over the world and Romania shares its place with the Dominican Republic and Botswana. 
The largest owner in the newspaper market is the Swiss group Ringier (it issues the best-selling tabloid newspaper, a sports newspaper and a daily newspaper), it included until February 2010 the bestselling business weekly Capital and other popular magazines (with television programs, magazines for women and for spare time activities).

The Swiss publishing house, however, has separated itself February 2012 from 2 publications issued in Romania. Ringier sold the newspaper Evenimentul Zilei and the economic weekly magazine Capital to the newly founded company Editura Evenimentul şi Capital, whose majority shareholder, the media entrepreneur Bobby Păunescu, cooperates among others with the American media mogul Rupert Murdoch.

The very rich, due to dubious real estate and banking businesses notorious Păunescu family already controls the Bucharest TV channel B1 through the company News Television. The station $B 1$ was one of the most important propaganda channels of the former President Traian Băsescu. Ringier Romania explained that they wanted to consolidate the online segment while focusing on the tabloid Libertatea and on the women's magazine Unica.

Regarding the independence / dependence of the press it must be said that "Cotidianul" is part of the media empire RealitateaCaţavencu owned by the businessman Sorin Ovidiu Vântu, also containing further TV and radio stations (TV channels: Realitatea TV, The Monney Channel, Romantica; radio stations: Radio Realitatea FM and Radio Guerrilla), a newswire as well as the popular political weekly Academia Caţavencu. The most successful daily newspaper in Romania, Adevărul, belongs to the former oil businessman Dinu Patriciu, who in 2008 had sold his shares for Romania's second-largest oil company Rompetrol and then declared that he would devote himself to cultural projects.
Pro TV is part of the media group CME, while Antena belongs together with the TV channel Euforia Lifestyle to the media empire Intact also owned by the Voiculescu family.

Owner of Europa FM is the French entrepreneur Legardere (through the Share Company Europa Developpement International - R SA), regarding other private stations owned by different media moguls, excepting the already mentioned families, Silviu Prigoană is an important name, his are the less prominent radio stations Etno FM, Sport FM and the TV stations Etno TV and Taraf TV.

These include the 2nd and 3rd most popular TV stations Antena and Euforia Lifestyle, the most popular Radio station in Bucharest, Radio $\mathrm{Zu}$ (together with the radio station Romantic), the most widely read sports newspaper Gazeta Sporturilor and others. The founder of this media empire is the former collaborator of the communist security, Dan Voiculescu, also known by his code name "Felix". Although the now 67-year-old man describes himself as a simple pensioner, because he has transferred almost everything on the names of his two daughters, he played until recently an important role in the politics of Romania, as the founder of one of the main parties - the Conservative Party (Partidul Conservator) and as a member of the Senate until 2013.

\section{Media Moguls in Crisis}

Dan Voiculescu gets arrested on the 8th of August 2014 and is sentenced to 10 years in prison for his part in the illegal privatization of the Research Institute for Food Bucharest. Because of this, the private property of the Intact media group including the new building of the TV station Antena have been confiscated.

After the arrest of Dan Voiculescu, his daughter Camelia Voiculescu, owner of the Intact Group has quickly reacted with a press release, the same stands for the journalists of the Antena 3 station. 
The sentencing of Dan Voiculescu and other arrested persons was interpreted as an abuse of the Romanian government. The entire news release was written in an extremely pathetic matter from a firstperson perspective (we, the journalists of the TV station Antena 3, the strongest and most credible media institution in Romania) and ends with a real appeal: "Come with us and we can (collectively) put an end to the abuse!" in the name of ,the journalists from Antena 3 "(to be read on www.stiripesurse.ro).

The Director-General of the television station Antena 3 and one of the most famous $\mathrm{TV}$-journalists of this private station, Mihai Gâdea, wrote a letter to the President of the Senate, expressing himself against the arrest of Dan Voiculescu. In this he calls for a detailed examination by the National Anticorruption Department to clarify the "abuse" as well as the main reason for the arrest (to what extent the research institute had been privatized under legal circumstances) and comes out against the confiscation of the building in which the private broadcaster has its headquarters. This letter is signed in the name of "the journalists from Antena 3" (see more on www.ziare.com). The letter arrives on 18th of August in the Senate, 10 days after the sentencing of Dan Voiculescu.

On the 19th of August 2015 Dinu Patriciu, the other media mogul of Romania, died in a London hospital. Regarding the context information of this sudden news a flood of extremely questionable relationships arises in the media. Dinu Patriciu was a real Romanian businessman particularly by having purchased the former state oil refinery eight years after the fall of communism (1998). After 9 years, this oil company gains a profit of 8.6 trillion dollars and is sold in 2007 to an energy company from Kazakhstan, KazMunaGaz. Before that, Dinu Patriciu was President and CEO of the Rompetrol Group company, a multinational oil contractor with headquarters in the Netherlands, with offices in 13 states, the most important of which in Romania, France and in the countries of Southeastern Europe. Rompetrol was under his leadership one of the 25th largest oil companies in the EU. To the expansion program of the company belonged the Balkan region, especially Moldavia, Georgia and Ukraine, as well as the purchase of the largest French oil product company, Dyneff Group SA of France, in 2005. The last acquisition was that of the contractor Vector Energy, at the same time with the development of a Swiss trading line, which transformed Rompetrol into a bridge between the raw materials from Eastern Europe and energy demand from Western Europe. Before that, Patriciu was also the president of the Investment Committee of the Romania and Moldova Direct Fund, LP, a private investment fund established under American leadership in 1998. Among the investors were International Finance Corporation and DEG of the German government. Patriciu also owned the media company Adevărul Holding, which also includes today the best-selling information daily Adevărul, as well as the best-selling tabloid Click, and which also published yearly the rank list of the richest Romanians Forbs Romania, under the license of Forbes Media LLC. Patriciu was also one of the main members of the National Liberal Party of Romania and according to Forbes from 2007 until his death he remained the richest person in Romania. His fortune was in 2009 the 397 th largest in the world with assets of \$ 2.5 trillion. His fortune grew after the sale of Rompetrol thanks to his real estate investments, he had more than 40 domestic and commercial projects in Romania, 25 luxury apartments, offices and hotels even in the United Arab States (www.wikipedia.org).

Robert Turcescu, one of the most popular journalists of the younger generation (born 1975), with articles published in the quality newspapers Dilema and Dilema veche, known for his political TV show 100\% 
(2004 declared the best television talk show), winner of 4 journalistic awards (2001 - awarded by the Romanian Press Club, 2002 - by the National Television Commission, 2004 - by the Association of Television Professionals and 2005 for his contribution to the democratization of Romania), shocked the whole civil society by publicly recognizing on the $21 \mathrm{st}$ of September 2015, first on his blog and afterwards in a live broadcast on the TV channel B1, where he had been working in the last few years, that he had been a communist undercover officer and by publishing his alleged compensation certificates. He then explains in short that he will withdraw on the following Monday. In the live TV show, the formerly hard and objective journalist is no longer recognizable, his discourse is heavily affected by the religious component. He declares himself freed and pleased. The opinions of the laity and non-laity are divided, but it seems that no one believes in the journalists' confession. The approaching election campaign seems again to play an important role here: the private channel B1 is known for its sympathy towards president Băsescu. The latter also has a favorite candidate in the presidential elections: the former minister of Tourism Elena Udrea, which would like to have better quotas. The exact connection is not (yet) explored thoroughly by any newspaper or journalist. No trace of investigative journalism here.

\section{Political context today}

In December 2016 Romania's Social Democrats easily win parliamentary elections. But 2 years after the presidential elections and just one month after the parliamentary elections, beginning with the $22^{\text {th }}$ of January 2017 protests took place throughout the country against ordinance bills that were proposed by the Romanian Ministry of Justice regarding the pardoning of certain committed crimes, and the amendment of the Penal Code of Romania (especially regarding the abuse of power). Opponents raised accusations that the ordinance was intended for decriminalisation of government corruption, and to help hundreds of current and former politicians to escape ongoing criminal investigations or prison sentence. Immediately after it was announced that the ordinance was passed, more than 25,000 people protested that night. The protests swelled to over a half of million people throughout the whole country, making the protests the largest since the fall of communism and also in Romania's history as in [10].

On $8^{\text {th }}$ February 2017 the Department for Judges with the Higher Council of Magistracy, CSM, decided to exclude judge Camelia Bogdan from magistracy. Camelia Bogdan is the judge who, back in 2014, sentenced Dan Voiculescu to 10 years in prison in the case of the fraudulent privatisation of the Food Research Institute (ICA) in Bucharest as [11].

Robert Turcescu is since the last parliamentary elections in december 2016 deputy in the Romanian Parliament. He was elected as member of the People's Movement Party (PMP) of the former president Traian Băsescu. At that time Traian Băsescu was president of the PMP, but on the $1^{\text {st }}$ of February 2017 during the protests against the ordinance bill, Traian Băsescu announced that he resigned from the leader position and remain just a simple member of the party founded by his followers in 2013 as in [12].

\section{Conclusions}

The informations, the news are often use today as entertainment [13], the specialists named it "infotainment" [14]. Besides of that in Romania freedom is combined with quality in the mass communication, but also media policy lures journalists in the credibility trap and turns them in time of crisis into PR strategists, who sign press releases instead of conducting investigative journalism. To what extent one can speak 
today of a turning point in Romanian society and at the same time of an advancement regarding the path of free media in Romania remains, unfortunately, still partly up to debate. The discussed cases show, especially in an acute preelection campaign, that media too can be the victim of well-orchestrated campaign propaganda. The last protest shows that actually the civil society can still play a role. At least a major part of civil society has become from a passive spectator of the power struggles, without knowing exactly with whom or whether it still wants to vote an active player. If the mass media can reflect impartial reality is still a questionable issue.

\section{References}

[1] Centrul pentru Jurnalism Independent (2004). Structurile de proprietate şi influenţa lor asupra independenţei şi pluralismului în mass media. România. Republica Moldova aus: Media ownership and its impact on media independence and pluralism. Ljubljana: Peace Institute, Institute for Contemporany Social and Political Studies.

[2] Active Watch - Agenţia de Monitorizare a Presei (2008). Evaluarea nivelului de competenţă în mass media, Bucureşti.

[3] Martin, R. Ulmanu, A.B. (2016). De ce şi cum se clatină TVR. Mărturii din interiorul televiziunii publice. Bucharest. from http://www.activewatch.ro

[4] Centrul pentru Jurnalism Independent (2016). Libertatea de exprimare în legislaţia românească. O colecţie de prevederi legale româneşti şi studii de caz. from http://www.cji.ro/libertatea-de-exprimare-in-legislatia-romaneasca-3/

[5] http://www.riseproject.ro

[6] http://www.freedomhouse.org

[7] Allgemeine Deutsche Zeitung (2010), 4328, 13th of February, 2010

[8] http://www.brat.ro

[9] http://www.ziare.com

[10] https://en.wikipedia.org/wiki/2017_Romanian_protests

[11] http://www.rri.ro/en_gb/february_8_2017_update-2559762

[12] https://ro.wikipedia.org/wiki/Partidul_Mișcarea_Populară

[13] Magazin-Deutschland.De (2009), 6

[14] Bachmann-Stein, A. (2008). Infotainment und Häppchenjournalismus. Sprach- und medienhistorische Überlegungen zum Wandel von Pressetexten. In: H.H. Lüger \& H. E.H. Lenk (Eds.): Kontrastive Medienlinguistik. Landau: Verlag Empirische Pädagogik. 